\title{
Information Technology and its Impact on the Predictive Ability of Accounting Information by Using the Application of International Financial Reporting Standards (IFRSs)
}

\author{
Sabeha Barzan Farhood \\ Post Graduate Institute of Accounting and Financial Studies, Department of Accounting Studies, \\ University of Baghdad, Iraq
}

\begin{abstract}
The study aims to measuring the predictive ability of accounting information using the application of international financial reporting standards in a sample of companies. A group of companies listed in the Iraqi Stock Exchange were selected and divided into two groups. The first one included commercial banks that applied the accounting standards. They have accounting programs and apply electronic systems In the completion of its research, the second group have electronic accounting software and use electronic systems in a limited manner in the completion of its research but did not apply international financial reporting standards, Kida Model has been used to measure the predictive capacity of accounting information and measuring the performance of all companies. The research found that whether companies applied information technology or IFRSs, there are other factors that affect the performance of research sample companies: The low liquidity index of the companie's research sample as a result of decrease in operating income. The decline in the market value of property rights which are affected by some factors, including economic factors which was the austerity in 2016 for these sample of the research, political and security factors which was a presence in three provinces of Iraq which makes current and prospective investors refrain from buying interest in the companies sample search. The decline in operating profits due to the decrease in sales revenues of the two companies which was caused by the lack of government support for national products and the presence of competing products in the market at the lowest price and in large quantities. The decrease in the cash assets of the companies in the research sample and directing them towards long-term investments while their short-term liabilities are high. This leads to a lot of commitments on the company that have not been paid on due dates, leading to mistrust between the company and the parties that deal with it.
\end{abstract}

Key words: Information technology, predictability of accounting information, IFRS, Kida Model, mistrust, revenues

\section{INTRODUCTION}

The development of technology and electronic programs in the world has cast a shadow over the profession of accounting as a result of the great development and expansion witnessed by economic units in all sectors, industrial and commercial. The qualitative characteristics of accounting information have been a major part of this change. In the performance of its work and its various production, marketing and administrative departments, the use of information technology in the economic units has a great role in facilitating the business and operation of electronic workings which leads to ease in and accounting information which in turn reduces the effort made by accountants both in terms of accounting operations or other operations that take place in the data and calculating the results, it is necessary that companies seek to choose the system that is appropriate to the nature of its activity and to evaluate and maintain it constantly so as not to lose quality. Under the directives of the Central Bank of Iraq to apply the international accounting standards and international financial reporting standards in the banking industry in order to enhance the qualitative characteristics of information and thus provide accounting information appropriate to make good decisions. The importance of the research is that the existence of methods to evaluate the performance of companies when using or applying new mechanisms or methods leads to the possibility of periodic evaluation of performance, thus, recognizing the usefulness of using information technology or new techniques, preferring to use the best and most recent methods to provide 
accounting information to evaluate the feasibility use new techniques or mechanisms. The current research tackles the problem of the failure of the research sample companies periodically to evaluate their financial performance using advanced methods of forecasting in the application of the international accounting standards. Although, some companies use the research sample technological method in addition to the above the problem of research is determined in the following questions:

- Does the application of information technology increase the predictive capacity of accounting information?

- Do IFRSs increase the efficiency of predictive accounting information in companies that have applied it?

To achieve the research objectives, the research hypotheses were formulated as follows:

The first hypothesis: The application of information technology is reflected in the predictive ability of accounting information under international financial reporting standards.

The second alternative hypothesis: The performance of companies in the research sample is influenced by other factors not related to information technology and international financial reporting standards.

The ability of accounting information under the technology environment will be highlighted by identifying the feasibility of applying international accounting standards in sample research companies. The aim of the research is to identify the most important means of information technology applied in the research sample companies and to know the effect of information technology on the predictive ability of accounting information in a sample of companies that did not apply international accounting standards in their accounting work. In the light of information technology and to recognize the reflection of the application of international accounting standards on the predictive ability of accounting information under the shadow of information technology.

In order to achieve the objectives of the research, the research was dealt with four topics, the first one was devoted to the introduction and the previous studies, the second topic was devoted to the theoretical side, while the third section was devoted to the presentation of the practical side and test the hypotheses to reach some conclusions and recommendations.

Society and research sample: The research community is represented (101) banks listed in the Iraqi Stock Exchange, for the year 2016, the study sample was (10) which is represents $10 \%$ of the total banks for the mentioned year, so to test the research hypothesis the research sample was divided into two parts:

- Six companies apply international accounting standards and apply information technology extensively

- Four companies applied information technology in a limited manner and did not apply international accounting standards

\section{Search form}

Literature review: Chan and Tam (2011) studied the aim of the study was to provide a comprehensive set of IT skills suitable for accounting graduates in New Zealand City and to develop the model for obtaining the content of the information technology in the curriculum. The study presented the following results:

- The daily need for advanced skills by graduates at the beginning of work

- Basic knowledge of accounting graduates must have theoretical knowledge of business systems and accounting

- The daily need for good knowledge of accounting systems to complete skills in accounting software

Moorthy at el. (2012) analyze the use of Information Technology (IT) in administrative accounting as well as the advantages and disadvantages of IT adoption in management accounting. IT changes frequently and accounting standards remain for many years without any major change. IT and management accounting are vital for both small and large organizations. Organizations and communities have always stressed the need for a shift in the education of accountants by increasing knowledge of IT systems. This study examined the relationship between information technology and management accounting. She also pointed to the possibility of using information technology in administrative accounting which will simplify the calculation process and provide better options applicable to the company's data for effective decision making. The results of the study also indicate that information technology has a significant impact on costs as the application of information technology will result in a large expenditure on the hardware and software 
and IT staff. The study also showed that information technology can improve the efficiency of the accounting department and provide results easily and effortlessly and in a timely manner and accurately and gave accountants special attention to information technology.

Sarokolaei at el. has tried to find out how effective IT is on the effectiveness of accounting data and reports. Using statistical analysis methods and Friedman's test to classify determinants, they examined the effectiveness of information technology on factors such as time saving and data presentation, consistency of accounting data and change in economic conditions, ease of interpretation of data resulting from desirable data quality as outputs and the variety and format of outputs related to decisionmaking. The study selected an appropriate sample of the statistical community from the managers of listed companies to assess the effectiveness of information technology on the factors related to the financial statements. After analyzing the data, the study concluded that effective information technology affects the effectiveness of the data generated by the accounting system.

Qatawneh (2012) in a study to show the need to identify electronic commerce and the accounting information system as an important development in the business world which leads to reducing the operating costs of banks. The basic analysis showed that electronic commerce has a positive effect on the accounting information system. There is a significant statistical relationship between the components of the accounting information system.

Manic Sacer and Oluic (2013) in order to understand the impact of information technology in the accounting procedures and consequently in the quality of accounting information systems, the study analyzed the basic characteristics of the accounting information system. In order to understand the quality of the accounting information system by accountants in a sample of medium and large companies in Croatia, Applied studies in the years 2001, 2008 and 2012. The study concluded that the quality of the accounting information system is influenced by many factors that can not be imagined without the use of appropriate information technology and the impact of information technology in the manner in which the accounting information system is managed and how it contributes, handles, handles and receives accounting information which will contribute significantly to the accuracy and timeliness of providing this accounting information, thus, in the quality of the accounting information system.

Eng at el. (2005) through the study, they studied the predictive value of profits, operating cash flows and accruals in Hong Kong, Malaysia, Singapore and Thailand for the period 1994-2001. The impact of the Asian financial crisis of 1997 on the predictive power of accounting performance measures was also examined. The future cash flows and the increase in future income were reviewed on the profits (or cash flows and receivables) for the periods 1994-1996 (pre-crisis period), 1997-1998 (crisis period) and 1999-2001 (post-crisis period). The study pointed out that the increase in revenues one year ago that investors have underestimated the accounting procedures in pre-crisis and post-crisis periods and over-estimated the actions during the crisis period.

While Okab and Al-Oqool (2014) determine the role of accountants in the life cycle of the electronic accounting system in the most important Jordanian economic sectors which is characterized by the use of information technology in providing data in the banking sector. The study obtained the following conclusions.

The accountants play a role in the life cycle of activities under the electronic accounting information, during the various stages of the electronic accounting information system by planning the use of the proposed system, preparing a website, purchasing equipment and expertise, training the employees after the system is finally upgraded, programs that will be used to run the system and check the system to make sure it can be used without any problems and thus test the system completely.

The participation of accountants in the life cycle of the electronic accounting information system achieves many advantages for the banks. The research sample includes reducing the risks related to the electronic system in such a way as to provide suitable information to the users.

The study found that accountants under the electronic accounting information system face several different determinants which include weak functional skills and knowledge related to information technology. Awosejo at el. (2013) concluded by using statistical reasoning that the use of AIS is relatively acceptable within accounting firms, largely due to the "change" that comes with the use of this application. The use of the AIS system, a computer application that has brought a new direction of change from the traditional accounting method to a computer method has not been made possible by most people who are willing to adapt or have trouble adapting to it. It is clear that use is heavily affected and it has also been shown that most new users fall within the diploma level and have little experience in using computers. This creates a kind of difficulty in the effective use of available applications. The use of the automated knowledge system is seen to improve the productivity of 
user's work. In addition, the study found that all three factors that affect the AIS process have a direct effect on although, no direct effect is observed on the process on behavioral targets. This approach should therefore focus on initiatives to build and disseminate creativity to develop user behaviors that help to act and effectively use information technology.

Alves (2010) take into account organizational changes related to information technology and their impact on the function of management accounting and their relevance to the knowledge structure on the impact of information technology on the ability to resolve accounting functions. The relationship between information technology The quality of accounting practices was investigated using a study of 6 cases. It measured the impact of information technology on accounting functions. The results indicated a trend of change and decentralization of accounting functions. $\mathrm{He}$ concluded that the companies studied had high levels of investment in information technology. The sales/marketing area was greater use of laptops compared to other areas due to the nature of their activities, especially the greater need to work outside the company boundaries. The collected data showed that many documents with the accounting information used in the studied areas are produced locally and the purpose of using these documents was analyzed, the researcher found that, regardless of their origin, accounting documents are mainly used to provide projections and to identify corrective actions. The study found that the practice of decentralization in the performance of tasks is a traditional method in the accounting department.

The current study presents a model consisting of three variables: information technology, international financial reporting standards and the ability of the accounting information contained in the financial statements to enhance the predictive ability of accounting information through the use of Kida Model to predict the performance of companies in the study sample. While the current study used a model to evaluate the predictive capacity of companies and the extent of IT impact on international financial reporting standards and research, by using a group of companies with various activities (banking, industrial, hotels, telecommunications).

Theoretical framework and background: The Information Technology and accounting information: IT has proven to be an important and essential factor in the accounting information system and organizational performance. It can be said that IT has been able to increase the speed in the preparation of financial reporting, the reliability and accuracy of these reports which have a transparent and frank effect In dealing with the company with customers, partners and foreigners, thereby enhancing the overall success of this company. ICT has had a significant impact on the organization's accounting system and its organizational performance. The extent to which it covers the few defects. she has The benefits of communications, globalization and job creation have been provided. The efficiency of accounting practice, increased productivity, high turnaround rate and the profit of any organization is a result of the impact of ICTs. Taiwo (2016) the use of information technology on a large scale through computers and peripheral equipment has been a tremendous growth in service industries at present. Especially, in the banking industry. By introducing all banking activities in information technology into online banking, electronic payments, security investments and information exchange, banks now offer more diverse services to customers and less use of human resources (Berger, 2003). Due to this pattern of growth, it has shown that accounting information technology can make an equal contribution to profits, but mismanagement of IT due to technical problems, communication problems, training and maintenance has become the most important problem in the banking sector (Awe, 2002). Consequently, such failure may result in lower productivity, loss of IT assets and loss of important and confidential data. Despite these obstacles, most banking sector players are planning to apply IT again.

IFRSs and accounting information: IFRSs are intended to be applied by profit-orientated entities. These entitie's financial statements give information about performance, position and cash flow that is useful to a range of users in making financial decisions. These users include shareholders, creditors, employees and the general public. A complete set of financial statements includes:

- A balance sheet

- A statement of comprehensive income

- A cash flow statement

- A statement of changes in equity

- A description of accounting policies

- Notes to the financial statements

And to determine whether the financial statements provide complete information that can be investigated through disclosure requirements in the applicable accounting standards. Additional disclosure requirements under IFRS should affect positively the quality of accounting (Daske and Gebhardt, 2006). However, Paredes (2003) finds that accounting information users may become overloaded with information and make worse decisions because of more information and disclosures. The mandatory adoption of IFRSs is the most appropriate and useful disclosure Requirements to facilitate decision-making by stakeholders and therefore, 


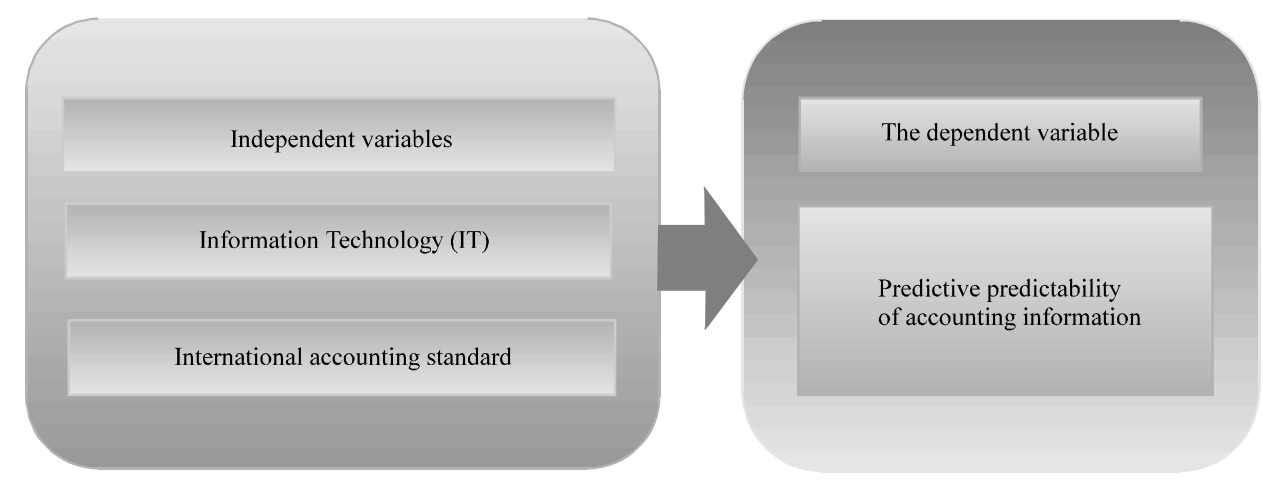

Fig. 1: Research form ( prepared by researcher)

there is no further information. The accuracy of accounting standards and the improved protection of investors are made by increasing estimates in profit Fig. 1. The application of IFRSs has prevented the accounting of a reservation but it still fails to prevent profit management practice. Accounting for a reservation is low on the importance of accounting information but profit management practices have a negative impact on the importance of information (Badloe, 2011).

Gossner (2015) examined whether the adoption of International Financial Reporting Standards (IFRS) has led to a deterioration in the quality of financial reports of German companies. The thesis measured financial statements with predictive profit potential in terms of operating cash flow forecasting and a profit-based cash flow forecasting model, making their application a significant contribution to the empirical financial accounting literature and predicting profit-based cash flow projections. With current revenue components. These components are current cash flow and current receivables. Current entitlements are expense expenses, amortization expense, accounts receivable instruments.

The thesis concluded that the error forecasting of the cash flow forecasting model is increased after the presentation of IFRS. This means that the predictive profit potential for forecasting operating cash flows has declined, indicating that the quality of profits and the quality of the financial statements have eventually declined and the German public companies have deteriorated. In a broader sense, the asymmetry of information between investors and managers of German public companies to change the accounting policy The result is strong for a variety of sensitivity tests related to model estimation method.

While Emekaponuzo et al. (2017) the adoption of IFRSs has led to changes in accounting systems.
Changes are essential aspects of the implementation of IFRS, particularly the implications of the audit profession as these issues have been identified as the focus of this paper. Survey design is supported. Auditors in accounting and auditing firms in Anambra and Akwa Ibom of Nigeria were target targets. The 120 arbitrators were selected randomly using the appropriate method and judicial report. Data were collected using the Likert scale questionnaire 5 points. Data were analyzed using descriptive statistics such as averages, weights and order. The study revealed that it changed as a result of the use of technology, changed as a result of the application of IFRS and require high experience in the field of information technology from auditors because they need to understand modern software. It is therefore, recommended that auditors take the challenge of updating their knowledge and skills in relation to IFRS and IT to prepare for future challenges. Similarly, accounting training institutions such as higher education institutions and the role of vocational education should modernize their curricula to meet the requirements of IFRS; the IFRS training packages and training programs should be cost-effective in Nigeria.

Predictive ability of accounting information: Prediction is defined as a set of objective procedures and methods that are designed to predict what happens in the future to economic units and to try to identify the results that will be achieved, so, predicting or planning the most important criteria for measuring the quality of accounting information will be their ability. Information is more predictable as it is more qualitative because one of the most important goals of financial information is to use real information about the past to predict future information. Forecasting is a way to use past and present accounting 
information to predict the performance of the For economic units in the future and thus help in planning and decision making, so, the quality of accounting information in their ability to predict and thus provide accounting information for management to make decisions that reduce the uncertainty.

One of the most important characteristics of accounting information is the achievement of quality that expresses its efficiency and effectiveness. The quality criterion means the availability of the elements of convenience and trust. The element of convenience includes timing and feedback. Correction in all cases in addition to predictability, in the sense that the information used in decision-making is predictive of the future and is based primarily on the confidence criterion in the information that the information used is characterized by The credibility and trust you are dealing with and which includes the true representation is that this information is expressed honestly about the financial transactions that are presented as well as the possibility of impartiality which means impartiality in the judgment of things and the lack of intent to modify and switch that affect the user of that information to the ability to achieve the corresponding expression of the concept of objectivity, which means the degree of agreement between the standards used by the actors to reach the results of a rough approximation (Angell and Steven, 1991).

Financial analysis is one of the methods of predicting the performance of companies which is defined as the process of determining the financial strength and weaknesses of the economic unit by finding a suitable relationship between the items in the financial statements (Ravinder and Anitha, 2013). The analysis of the financial statements is mainly explained to determine the financial and operating performance of the economic units through the use of a number of techniques or techniques to analyze the financial statement. The following are common methods which are widely used by economic units (Paramasivan and Subramanian, 2006) The most important characteristics of financial analysis.

Prediction mode: The Kida Model was used for the purpose of testing the hypotheses to predict the performance of companies in the research sample. This model was built in 1981 and this model is also composed of five financial ratios. These ratios are composed of liquidity ratios, financial ratios, profitability ratios and the higher the probability of default, the higher the probability of default. The higher the trend, the more stable the company. The model proved predictive capacity for bankruptcies of $91 \%$ a year before the occurrence of bankruptcy. Using the following equation.

\begin{tabular}{ll}
\multicolumn{2}{l}{ Table 1: the companies as research sample } \\
\hline No. & Company \\
\hline 1 & Cihan Investment Bank \\
2 & United Investment Bank \\
3 & Babylon Bank \\
4 & Al-Mansour Investment Bank \\
5 & Al-Khaleej Commercial Bank \\
6 & National Islamic Bank \\
7 & National Chemical and Plastic Industries \\
8 & The National Company for Metallurgical Industries \\
9 & and Bicycles \\
10 & Ishtar tourist hotels \\
\hline
\end{tabular}

Kida Model:

$$
Z=-1.042 X_{1}+0.427 X_{2}-0.461 X_{3}-0.463 X_{4}+0.271 X_{5}
$$

When:

$\mathrm{X}_{1}=$ Net income/Total assets

$\mathrm{X}_{2}=$ Total equity/Total debt

$\mathrm{X}_{3}=$ Fast assets/Short term traded liabilities

$\mathrm{X}_{4}=$ Revenue/Total Assets

$\mathrm{X}_{5}=\mathrm{Cash} /$ Total assets

\section{MATERIALS AND METHODS}

For the purpose of achieving the study objectives, the researcher used the theoretical side of scientific resources available in libraries or the books or master's thesis or doctoral dissertations that published on website or what is available in the periodicals. So, the practical side, relied on the Kida model represented by the equation below to predict the performance of companies.

Kida Model:

$$
Z=-1.042 X_{1}+0.427 X_{2}-0.461 X_{3}-0.463 X_{4}+0.271 X_{5}
$$

- Search limits

- Spatial limits

Including a group of private companies of various sectors listed in the Iraqi Stock Exchange as follows (Table 1):

Time limits: The Kida Model was applied to the financial statements of the sample companies for the financial year ended 31/12/2016 to forecast the performance of the companies. The accounting information for the same companies was used for the financial statements for the year ended 31/12/2017 and the first 6 months of 2018 for the purpose of validating the estimating of the research by applying the two models. 


\section{RESULTS AND DISCUSSION}

Experimental study: To test the hypotheses of current study, Kida was adopted to measure the predictive ability of accounting information insight the application of information technology and International Financial Reporting Standards (IFRS) for a sample of companies listed on the Iraqi Stock Exchange. A sample of companies were grouped as companies that apply information technology IFRS vs. not apply IFRS .

Brief summary of the companies used in the current study. The most important technical applications in the sample study companies. Information Technology ( IT) provided by the six banks sample study. The following are the types of electronic services that depend on the technical applications and information technology provided by the six banks of the study sample:

Banks apply the latest version of banks system. Apply the subscription system as well as convert the electronic field of correspondence from Org to Com which would facilitate a lot of procedures for collection and deposit by the parties with the banks. Increase courses for applications of electronic accounting software for employees in banks sample research.

Increase the special courses using the banking systems such as special adjustments to accounts, especially updates to the systems in force in banks. Banks use electronic financial reports to meet business requirements and provide financial data to their users with ease. Open a special website for each bank to present all quarterly and annual financial statements and review all changes that occur in the first place, so that, the beneficiaries of this data will be informed of all developments, especially, the shareholders and customers of the bank.

Electronic card services: The bank is keen to provide the latest electronic services to its customers in line with their requirements and expectations. The electronic services package was designed by the Bank in a way that gives its users easy and convenient during use and with the highest levels of safety while continuously developing these services and products. And in line with the financial needs of the bank's customers while the types of electronic services provided by each bank: Visa services, AMT, Online bank service, Q-Card service, service of the content of the Visa VBV, service of text messages SMS notification. Types of technical information used by $\mathrm{AL}-\mathrm{Khattem}$ telecommunications company:
- Prepaid subscriptions

- Internet services

- Long term payments

The development of the self-service system for subscribers within the official website of the company as well as its use as an application on mobile phones. Expansion of the database store in terms of storage capacity. Types of technical information used by National Bank of Metal Industries and Bicycles

The two companies did not rely on the production of technicalinformation and used traditional mechanization in production and did not take advantage of the technological capabilities used in international or Arab companies which produce similar products and only what it has available for decades. The marketing, research and development departments did not use modern technology to develop their business.

Accounting departments rely on the use of the electronic calculator to cover all its activities (finance, stores, salaries, wages, cost, sales, shareholders) through the advanced communications network and rely on the scientific means of control and data storage. Complete a website for each company on the internet. Types of technical information used by Ishtar tourist hotels.

A website of the hotel is available through which anyone can pre-book and the hotel is electronically installed. Wi-Fi is available for hotel guests $24 \mathrm{~h}$ a day. ATM machine and currency exchange are available. ATM machine and currency exchange are available on site. The Company did not use any accounting programs or accounting programs because the organization of its accounts is prepared by the office of the organization of external accounts. Applying Kida Model on financial data of the sample companies

Table 1-3 shows applying Kida model on financial data of the sample companies to evaluate $(\mathrm{Z})$ value for each company. Classification of companies according to Kida Model to predict financial failure. According to the results obtained from the previous Table 3 , the performance of companies will be evaluated according as failure and success in the table below.

Through the Table 3 and 4, companies can be arranged in descending order according to the value (Z-value) from the highest value to the lowest value as in the Table 5.

Babylon bank: It has the most value for success according to the Kida Model because the value of $Z$ was high compared with other companies sample research as the year 2016, the first year in which the Bank applies international financial reporting standards and the use of information technology and banking applications in all branches deployed in Iraq and the following are the main 
Table 2: Characteristics of companies

\begin{tabular}{lllll} 
Company name & Establish years & $\begin{array}{l}\text { Equity capital } \\
\text { (ID Iraqi Dinar) }\end{array}$ & Using (IT) & Using (IFRS) \\
Cihan Investment Bank & $3 / 2 / 2008$ & 25000000000 & Applied & Applied \\
National Islamic Bank & $28 / 1 / 2015$ & 25000000000 & Applied & Applied \\
Babylon Bank & $8 / 7 / 2004$ & 500000000 & Applied & Applied \\
Al-Mansour Investment Bank & $13 / 9 / 2005$ & 55000000000 & Applied & Applied \\
Al Khaleej Commercial Bank & $20 / 10 / 1999$ & 600000000 & Applied & Applied \\
United Investment Bank & $20 / 8 / 1994$ & 1000000000 & Applied & Applied \\
National Chemical and Plastic Industries & $23 / 10 / 1962$ & 150000 & Applied & Not Applied \\
The National Company for Metallurgical Industries and Bicycles & $28 / 9 / 1964$ & 250000000 & Applied & Not Applied \\
Ishtar tourist hotels & $22 / 8 / 1989$ & 50000000 & Applied & Not Applied \\
Al Khatem Company for Communications & $29 / 7 / 2013$ & 1829782653400 & Applied & Not Applied \\
\hline Prepare by the researcher, drawing on the reports of the Iraqi Stock Exchange on the website:http://www.isx-iq.net/isxportal/portal/homePage.html
\end{tabular}

Prepare by the researcher, drawing on the reports of the Iraqi Stock Exchange on the website:http://www.isx-iq.net/isxportal/portal/homePage.html

Table 3: Z-values according to Kida Model

\begin{tabular}{lcccccr}
\hline Properties/Company name & $\mathrm{X}_{1}$ & $\mathrm{X}_{2}$ & $\mathrm{X}_{3}$ & $\mathrm{X}_{4}$ & $\mathrm{X}_{5}$ & Z-values \\
\hline Using (IT) and (IFRS ) & & & & & & 0.110 \\
Cihan Investment Bank & 0.03 & 0.41 & 0.250 & 0.030 & 0.27 \\
National Islamic Bank & 0.03 & 0.33 & 0.130 & 0.030 & 0.070 & 0.27 \\
Baby lon Bank & 0.02 & 1.41 & 0.170 & 0.030 & 0.070 & 1.30 \\
Al-Mansour Investment Bank & 0.02 & 0.42 & 0.660 & 0.020 & 0.200 & $-(0.04)$ \\
Al Khaleej Commercial Bank & 0.01 & 0.28 & 0.005 & 0.014 & 0.057 & 0.33 \\
Using (IT) without (IFRS) & & & & & 0.040 & 0.045 \\
United Investment Bank & $(0.18)$ & 0.36 & 0.005 & 0.170 & 0.018 \\
National Chemical and Plastic Industries & $(0.05)$ & $(0.1)$ & 0.165 & 0.047 & 0.380 \\
The National Company for Metallurgical Industries and Bicycles & 0.048 & 0.017 & 0.606 & 0.032 & 0.001 & 0.572 \\
Ishtar tourist hotels & 0.002 & 0.672 & 0.442 & 0.021 & 0.027 & 0.238 \\
Al Khatem Company for Communications & 0.030 & 0.535 & 0.028 & 0.107 & 0.176 & 0.606 \\
\hline
\end{tabular}

Prepare by the researcher, depending on the financial statements of the companies

Table 4: Classification of companies according to Kida Model

\begin{tabular}{|c|c|c|c|c|c|c|}
\hline Company name & & Z-values & & & & Classification \\
\hline Cihan Investment Bank & & 0.27 & & & & Successful \\
\hline National Islamic Bank & & 0.27 & & & & Successful \\
\hline Babylon Bank & & 1.30 & & & & Successful \\
\hline Al-Mansour Investment Bank & & $-(0.04)$ & & & & Unsucc essful \\
\hline Al Khaleej Commercial Bank & & 0.33 & & & & Successful \\
\hline United Investment Bank & & 0.045 & & & & Successful \\
\hline National Chemical and Plastic Industries & & 0.38 & & & & Successful \\
\hline The National Company for Metallurgical & & 0.572 & & & & Successful \\
\hline Industries and Bicycles & & & & & & \\
\hline Ishtar tourist hotels & & 0.238 & & & & Successful \\
\hline Al Khatem Company for Communications & & 0.606 & & & & Successful \\
\hline Prepare by the researcher & & & & & & \\
\hline Table 5: the arrangement of the companies according to ( $\mathrm{Z}$-value & & & & & & \\
\hline Company name & $\mathrm{X}_{1}$ & $\mathrm{X}_{2}$ & $\mathrm{X}_{3}$ & $\mathrm{X}_{4}$ & $\mathrm{X}_{5}$ & Z-values \\
\hline Babylon Bank & 0.020 & 1.410 & 0.17 & 0.030 & 0.070 & 1.300 \\
\hline Al Khatem Company for Communications & 0.030 & 0.535 & 0.028 & 0.107 & 0.176 & 0.606 \\
\hline Ishtar tourist hotels & 0.002 & 0.672 & 0.442 & 0.021 & 0.027 & 0.572 \\
\hline The National Company for Metallurgical Industries and Bicycles & 0.048 & 0.017 & 0.606 & 0.032 & 0.001 & 0.380 \\
\hline Al Khaleej Commercial Bank & 0.010 & 0.280 & 0.005 & 0.014 & 0.057 & 0.330 \\
\hline Cihan Investment Bank & 0.030 & 0.410 & 0.25 & 0.030 & 0.110 & 0.270 \\
\hline National Islamic Bank & 0.030 & 0.330 & 0.13 & 0.030 & 0.070 & 0.270 \\
\hline United Investment Bank & $(0.18)$ & 0.360 & 0.005 & 0.170 & 0.040 & 0.238 \\
\hline National Chemical and Plastic Industries & $(0.05)$ & $(0.1)$ & 0.165 & 0.047 & 0.018 & 0.045 \\
\hline Al - Mansour Investment Bank & 0.020 & 0.420 & 0.66 & 0.020 & 0.20 & $-(0.04)$ \\
\hline
\end{tabular}

Prepare by the researcher

results achieved by the Bank and performance indicators and the most important investment decisions taken by the General Authority of the Bank based on the performance indicators for the fiscal year ended in 2017. The bank was listed among the top ten companies in terms of the number of shares traded in the Iraqi market for securities traded value amounted to the total value of trading by $4.05 \%$ of the total $85.25 \%$ for the year 2017 . It is a high index compared to the previous year 2016. The top ten in the number of shares traded by $3.14 \%$ of the total $75.15 \%$. Table 6 below shows the value of the share traded for 2017 compared to the value of trading in 2016. 
J. Eng. Applied Sci., 14 (8): 2620-2632, 2019

Table 6: The trading price of the Babylon bank's shares

\begin{tabular}{|c|c|c|c|c|c|c|c|c|c|c|c|c|}
\hline Stock value & Jan. & Feb. & Mar. & Apr. & May & Jon. & July & Aug. & Sep. & Oct. & Nov. & Dec. \\
\hline 2017 & 0.44 & 0.45 & 0.39 & 0.38 & 0.33 & 0.32 & 0.31 & 0.28 & 0.29 & 0.29 & 0.29 & 0.30 \\
\hline 2016 & 0.24 & 0.23 & 0.23 & 0.21 & 0.18 & 0.20 & 0.20 & 0.20 & 0.23 & 0.28 & 0.33 & 0.33 \\
\hline Diff. & 0.20 & 0.22 & 0.16 & 0.17 & 0.15 & 0.12 & 0.11 & 0.08 & 0.06 & 0.01 & -0.04 & -0.03 \\
\hline
\end{tabular}

Table 7: The trading price of Al Khatem company for communications shares

\begin{tabular}{|c|c|c|c|c|c|c|c|c|c|c|c|c|}
\hline Stock value & Jan. & Feb. & Mar. & Apr. & May & Jon. & July & Aug. & Sep. & Oct. & Nov. & Dec. \\
\hline 2017 & 4.32 & 4.00 & 3.30 & 3.50 & 3.80 & 3.80 & 3.42 & 3.25 & 3.25 & 3.20 & 3.25 & 2.68 \\
\hline 2016 & 3.06 & 2.86 & 3.05 & 3.05 & 3.05 & 2.70 & - & 2.95 & 2.95 & 2.75 & 3.00 & 3.26 \\
\hline Diff. & 1.26 & 1.14 & 0.25 & 0.45 & 0.75 & 1.10 & 3.42 & 0.30 & 0.30 & 0.45 & 0.25 & -0.40 \\
\hline
\end{tabular}

Table 8: The trading price of Ishtar tourist hotels shares

\begin{tabular}{|c|c|c|c|c|c|c|c|c|c|c|c|c|}
\hline Stock value & Jan. & Feb. & Mar. & Apr. & May & Jon. & July & Aug. & Sep. & Oct. & Nov. & Dec. \\
\hline 2017 & 13.55 & 13.5 & 13.2 & 12.49 & 12 & 12.25 & 11 & 11.35 & 11.5 & 12.6 & 12.25 & 12 \\
\hline 2016 & 11.8 & 11.3 & 11.55 & 10.3 & 10.85 & 11.3 & 11 & 11 & 12.35 & 13.3 & 14.3 & 13.3 \\
\hline Diff. & 1.75 & 2.2 & 1.65 & 2.19 & 0.15 & 0.95 & 0 & 0.35 & -0.85 & 0.70 & -2.05 & -1.3 \\
\hline
\end{tabular}

Table 9: The trading price of The National Company for Metallurgical Industries and Bicycles shares

\begin{tabular}{|c|c|c|c|c|c|c|c|c|c|c|c|c|}
\hline Stock value & Jan. & Feb. & Mar. & Apr. & May & Jon. & July & Aug. & Sep. & Oct. & Nov. & Dec. \\
\hline 2017 & - & - & - & 0.49 & 0.63 & 0.72 & 0.72 & 0.66 & 0.60 & 0.65 & 0.63 & 0.72 \\
\hline 2016 & - & - & - & - & - & - & - & - & - & - & - & - \\
\hline Diff. & - & - & - & 0.49 & 0.63 & 0.72 & 0.72 & 0.66 & 0.60 & 0.65 & 0.63 & 0.72 \\
\hline
\end{tabular}

The researcher notes the increase in the value of the stock when trading in all the months of 2017 when comparing the value of shares in trading for the year 2016 , except for the simple difference in the last two months of the year. This indicates the success of the bank and its performance confirms the Z-value according to the Kida model.

Al-Khatem company for communications: It is considered as successful company according to the Kida Model because the $Z$-value was positive, the company applied IT in its work but it did not apply international financial reporting standards because the CBI did not obligate the telecommunications companies but obliged all private banks to apply international standards for financial reporting. Table 7 shows the change in the value of shares traded between 2016 and 2017, noting the decline in the values of $(\mathrm{X})$ despite being classified as successful companies. It is due to the rapid decline in assets $\mathrm{A}$ shift to cash in relation to total assets as well as a decrease in liquid cash assets to total assets. This means lower liquidity for the bank. Despite the increase in the ratio of net profit to total assets, the basis of maturity applied to the bank led to show the proportion of revenues from the activities of the bank compared to total assets positive ratio despite the low liquidity and rapid liquidity.

Ishtar tourist hotels: When reviewing the reports of the Iraqi market for securities, the researcher did not find any significant events for the year 2017 but when the researcher analyzed the reasons for the low success rate found that the decline in the profitability ratio that relate to net profit achieved compared to the total assets negatively impacted the value of trading shares for the year 2017, especially, the last four months of the year as compared to the value of trading shares for the same period of 2016 , shown in Table 8 . The company did not apply international standards for financial reporting but used information technology in its daily activities.

The National Company for Metallurgical Industries and Bicycles: Through the test of the reports on the Iraqi market for securities, the researcher found that the suspension of trading for the year 2016 due to lack of interest on the company's products and low revenues as the company requested to protect its products and not to increase the competing products in the market and the protection of the national product which has greatly affected the profits and revenues and thus the market value of its shares being traded which confirms the decline in the market value of the equity relative to the total debt or liabilities incurred by the company as well as the decline $Z$ profitability index of the company resulting from the decline in revenue and achieve deficits as well as low liquidity. Although, the classification according to the Kida Model but the success rate is very low and Table 9 shows not to include the company in the trading for the year 2016 and the simple value of shares for the year 2017 because of partnership contracts according to market reports and decisions taken in a timely manner. Information technology in the productive sectors and the Central Bank of Iraq does not have to apply the International Financial Reporting Standards (IFRS).

Al-Khaleej Commercial Bank: The success rate was very low for the bank despite the fact that the bank applies 
Table 10: The trading price of Al Khaleej Commercial Bank shares

\begin{tabular}{|c|c|c|c|c|c|c|c|c|c|c|c|c|}
\hline Stock value & Jan. & Feb. & Mar. & Apr. & May & Jon. & July & Aug. & Sep. & Oct. & Nov. & Dec. \\
\hline 2017 & 0.54 & 0.53 & 0.45 & 0.45 & 0.37 & 0.36 & 0.34 & 0.34 & 0.34 & 0.33 & 0.35 & 0.39 \\
\hline 2016 & 0.44 & 0.45 & 0.41 & 0.40 & 0.34 & 0.39 & 0.40 & 0.39 & - & 0.44 & 0.45 & 0.45 \\
\hline Diff. & 0.10 & 0.08 & 0.04 & 0.05 & 0.03 & -0.03 & -0.06 & -0.05 & 0.34 & -0.11 & -0.10 & -0.06 \\
\hline
\end{tabular}

Table 11: The trading price of Cihan Investment Bank shares

\begin{tabular}{|c|c|c|c|c|c|c|c|c|c|c|c|c|}
\hline Stock value & Jan. & Feb. & Mar. & Apr. & May & Jon. & July & Aug. & Sep. & Oct. & Nov. & Dec \\
\hline 2017 & - & - & - & - & - & 2.7 & 2.75 & - & - & 2.75 & 2.75 & 2.75 \\
\hline 2016 & - & - & - & - & - & - & - & - & - & - & - & - \\
\hline Diff. & - & - & - & - & - & 2.7 & 2.75 & - & - & 2.75 & 2.75 & 2.75 \\
\hline
\end{tabular}

information technology in all its banking transactions as well as the existence of international accounting programs to be implemented and the commitment of the bank to the instructions of the Central Bank of Iraq in applying the international financial reporting standards to its financial statements for the fiscal year ended 31/12/ 2016 but the decline of the following indicators clearly affected the value $(Z)$ according to the Kida model .

The bank's profit from the activities in relation to the value of the assets which has greatly affected the success rate of the bank according to the above index and the result of lower operating revenues of the bank. The decline in the market value of equity relative to the total debt, resulting from the low liquidity ratio (quick assets/total short-term liabilities)

The decrease in the ratio of cash assets compared to the total assets of the bank resulting from the decrease in bank deposits of all types. Table 10 shows the performance of stocks during trading in the first 6 months of 2017, slightly higher than the previous year (2016) and the decline in the last 6 months but more than the increase that occurred at the beginning of the year.

Cihan investment bank: We note the decline in trading indicators for shares in the last 6 months of 2017 and the success rate was very low for the bank, despite the fact that the bank applies information technology in all its banking transactions as well as the existence of international accounting programs to be worked out and the commitment of the Ceyhan Bank guidance of the Central Bank of Iraq on The application of International Financial Reporting Standards (IFRS) to its financial statements for the fiscal year ended 31/12/2016. However, the following indicators decreased significantly in the value of (Z) according to Kida model:

- The bank's profit from activities is less than the value of assets which has a significant impact on the value of $Z$

- The low operating income achieved by the bank for the year 2017
- The market value of equity was low relative to total debt, resulting from lower liquidity (fast assets/ shortterm liabilities)

- The decrease in the ratio of cash assets compared to the total assets of the bank resulting from the decrease in bank deposits of all types

- In the annual report of the Iraqi Stock Exchange for 2017 , no indication of any distinction or success of the bank through the decisions taken or classification of the bank among the most profitable or more traded

Table 11 shows the performance of stocks during trading in the first 6 months of 2017 , a very slight increase from the previous year (2016) and the decline in the last 6 months but more than the increase that occurred at the beginning of the year.

National islamic bank: The Bank has implemented a very low rate of success, noting that the bank applies information technology in all its banking activities as well as the existence of international accounting programs to be adopted and a commitment by the bank to the instructions of the Central Bank of Iraq in applying the International Financial Reporting Standards to its financial statements for the fiscal year ended 31/12/2016. But the decline of the following indicators significantly affected the $Z$-value according to Kida Model:

The decline in the market value of the equity and the result of the investor's interest in buying the shares of the bank. The profits achieved by the bank from the activities are small compared to the value of assets which has greatly affected the success rate of the bank according to the index above. Which resulted from lower operating income of the bank.

A decrease in the ratio of cash assets to total bank assets resulting from the decrease in bank deposits of all types. By looking at the core events of the bank, the suspension of trading for the year 2016 was due to the failure of the bank to provide an official answer to the events of substance and the trading of the bank shares for the year 2017. The answer was that the financial 


\section{J. Eng. Applied Sci., 14 (8): 2620-2632, 2019}

Table 12: The trading price of National Islamic Bank shares

\begin{tabular}{|c|c|c|c|c|c|c|c|c|c|c|c|c|}
\hline Stock value & Jan. & Feb. & Mar. & Apr. & May & Jon. & July & Aug. & Sep. & Oct. & Nov. & Dec \\
\hline 2017 & 1.02 & 1.12 & 1.15 & 1.15 & 1 & 1.05 & 1.05 & - & 1 & 1 & 1 & 1.21 \\
\hline 2016 & 0.9 & 1.02 & 0.94 & 1 & 1 & 1 & 1.1 & 1.15 & - & 1.17 & - & 1.1 \\
\hline Diff. & 0.12 & 0.10 & 0.21 & 0.15 & 0 & 0.05 & -0.05 & -1.15 & 1 & 0.17 & 1 & 0.11 \\
\hline
\end{tabular}

Table 13: The trading price of United bank for Investment shares

\begin{tabular}{|c|c|c|c|c|c|c|c|c|c|c|c|c|}
\hline Stock value & Jan. & Feb. & Mar. & Apr. & May & Jon. & July & Aug. & Sep. & Oct. & Nov. & Dec. \\
\hline 2017 & 0.40 & 0.40 & 0.35 & 0.43 & 0.28 & 0.26 & 0.24 & 0.21 & 0.21 & 0.22 & 0.24 & 0.23 \\
\hline 2016 & 0.32 & 0.30 & 0.27 & 0.23 & 0.21 & 0.21 & 0.22 & 0.22 & 0.23 & 0.28 & 0.31 & 0.31 \\
\hline Diff. & 0.08 & 0.10 & 0.08 & 0.20 & 0.07 & 0.05 & 0.02 & -0.01 & -0.02 & -0.06 & 0.07 & 0.08 \\
\hline
\end{tabular}

position of the bank is good and this in turn stimulated many investors to buy shares and rise in price in the last seven months of 2017.

Table 12 shows the performance of stocks during trading in the first 6 months of 2017 , a very slight increase from the previous year (2016) and the decline in the months of June and the month of August for non-trading, and returned to the rise.

United bank for investment: The researcher notes the low value of $(\mathrm{Z})$ according to the Kida Model of the United Investment bank. The bank applies information technology in all its banking activities as well as the existence of international accounting programs to be adopted as well as the bank's compliance with the instructions of the Central Bank of Iraq to implement international financial reporting standards on its financial statements for the year ended 31/12/2016. However, the following indicators decreased significantly in the Z-value according to the Kida model:

The decline in the market value of the equity and the result of the investor's interest in buying the shares of the bank. The bank's profits from the activities were small compared to the value of assets which greatly affected the success rate of the bank according to the index above. Which resulted from lower operating income of the bank. A decrease in the ratio of monetary assets compared to the total assets of the bank resulting from the decrease in bank deposits of all types.

By looking at the core events of the bank, the suspension of trading for the year 2016 was due to the failure of the bank to provide an official answer to the events of substance and was launched trading for the shares of the bank for the year 2017. The answer was that the financial position of the bank is good and this in turn stimulated many investors to buy shares and lower the price in the last 5 months of 2017.

Table 13 shows the performance of stocks during trading in the first 6 months of 2017, slightly higher than the previous year (2016) and the decline in the months of June and August for non-trading and returned to rise.
National chemical and plastic industries: The researcher notes that the percentage of the $\mathrm{Z}$-value is low according to the Kida Model of the company, noting that the company did not apply information technology in all its activities whether production, marketing or administrative activities as well as the absence of international accounting programs to be adopted in the accounting work, whether registration or deportation or the preparation of the final accounts as well as the non-application of the International Financial Reporting Standards (IFRS) to its financial statements for the fiscal year ended 31/12/2016. However, the following indicators decreased significantly in $\mathrm{Z}$ value according to the Kida Model:

Because of the existence of similar items of global origin and sold at lower prices than the company's products which in turn led to a decrease in the profits achieved by the company from the operating activities, a small relative to the value of assets which greatly affected the success rate of the company according to the index above. Which resulted from lower operating revenues. The decline in the market value of the company's equity due to the decline in the investor's interest in buying the company's shares.

The decrease in the ratio of monetary assets compared to the total assets of the bank resulting from the decrease in revenues for the presence of goods similar to the goods they produce and at much lower prices. In addition to the low support for the national product by the state.

Al-Mansour investment bank: The Bank's classification according to the Kida Model is in the category of failed companies. The bank applies information technology in all its banking activities as well as the existence of international accounting programs to be adopted and a commitment by the bank to the instructions of the Central Bank of Iraq in applying international financial reporting standards to its financial statements for the fiscal year Which ended on 31/12/2016. However, the decline in the following indicators clearly affected the value of $(Z)$ according to Kida Model: 
J. Eng. Applied Sci., 14 (8): 2620-2632, 2019

Table 14: The trading price of National Chemical and Plastic Industries shares

\begin{tabular}{|c|c|c|c|c|c|c|c|c|c|c|c|c|}
\hline Stock value & Jan. & Feb. & Mar. & Apr. & May & Jon. & July & Aug. & Sep. & Oct. & Nov. & Dec. \\
\hline 2017 & 0.61 & 0.61 & 0.52 & 0.55 & 0.52 & 0.56 & 0.53 & 0.5 & 0.49 & 0.5 & 0.5 & 0.57 \\
\hline 2016 & 0.53 & 0.52 & 0.48 & 0.47 & 0.39 & 0.41 & 0.42 & 0.4 & 0.39 & 0.44 & 0.52 & 0.52 \\
\hline Diff. & 0.08 & 0.09 & 0.04 & 0.08 & 0.013 & 0.05 & 0.11 & 0.1 & 0.10 & 0.06 & -0.02 & 0.05 \\
\hline
\end{tabular}

Table 15: The trading price of Al-Mansour Investment Bank shares

\begin{tabular}{lllllllllllll}
\hline Stock value & Jan. & Feb. & Mar. & Apr. & May & Jon. & July & Aug. & Sep. & Oct. & Nov. & Dec. \\
\hline 2017 & 1.1 & 1.05 & 0.94 & 0.89 & 0.85 & 0.73 & 0.76 & 0.78 & 0.74 & 0.74 & 0.75 & 0.79 \\
2016 & 0.84 & 0.90 & 0.82 & 0.85 & 0.85 & 0.96 & 0.90 & 0.96 & 0.95 & 0.95 & 0.99 & 0.99 \\
Diff. & 0.26 & 0.15 & 0.12 & 0.04 & 0 & -0.23 & -0.14 & -0.18 & -0.21 & -0.21 & 0.24 & -0.2 \\
\hline
\end{tabular}

The decline in the market value of the equity and the result of the investor's interest in buying the shares of the bank. The bank's profits from the activities were small compared to the value of assets which greatly affected the success rate of the bank according to the index above. Which resulted from lower operating income of the bank. The decrease in the ratio of cash assets compared to the total assets of the bank resulting from the decrease in bank deposits of all types.

The bank's financial position was good which in turn stimulated many investors to buy the bank's shares. Shares and rising price in the last 7 months of 2017. Table 14 and 15 shows the performance of stocks during trading in the first 6 months of 2017, a very slight increase from the previous year (2016) as well as the stability of the trading price of the stock in May and decline in the 7 months following non-trading.

Test study hypothesis: Following the application of the Kida method to the companies in the study sample, the first study hypothesis will be tested. The application of information technology is impacted in the predictive ability of accounting information in the application of international accounting standards. So, the following facts were noted:

All 6 banks applied the information technology in all their activities and have websites that publish and announce all facilities, loans and banking services as well as the application of international financial reporting standards but the results of the prediction indicate a low success according to the Kida Model which means that there are many factors the performance of the 6 banks affected the research sample, including the decrease in liquidity affected by the decrease in operating income which affects the realized profits which is a result of the decrease in cash assets compared to the total assets. As for the National Company for Chemical and Plastic Industries, the National Company for Metallurgical and Bicycle Industries, Ishtar Hotels Company and Al-Khatem Communications Company all of the reasons for the decline in the value of (Z) according to Kida model, despite being considered among the successful companies but very low rates as reported by the researcher in the analysis of the results, the decline in profits realized and due to the decline in operating income resulting from the decline in market values of its shares. Therefore, it rejects the first major hypothesis and accepts the second main hypothesis which states that the performance of companies in the research sample is influenced by other factors not related to information technology and international financial reporting standards.

\section{CONCLUSION}

Despite the use of information technology in all operational activities of the five successful research sample banks and their compliance with IFRS, the value of (Z) was low according to the Kida Model. Al-Mansour used information technology and adhered to international financial reporting standards but its performance was low and was considered a failed company according to the Kida Model.

The application of IFRS did not affect the financial performance of the sample banks. Despite the simple application of information technology in the research companies, the research sample and its non-compliance with the application of international financial reporting standards but its performance was close to the level of performance of the 6 banks. The Ishtar Hotels Company applied extensively to information technology and was not required to apply international financial reporting standards but the result of the evaluation was low.

Al-Khatem Telecom has applied IT in all its activities but has been classified as a successful and low-grade company and approach to successful companies according to the Kida model. The following are the factors that affect the performance of the companies in the research sample: the low liquidity index of the companie's research sample and the corresponding decrease in operating income.

The decline in the market value of property rights, which are affected by many factors, including economic factors which was the austerity that was in 2016 to the sample of the research, political and security factors, which was a presence in three provinces of Iraq which makes current and prospective investors refrain from 
buying interest in the companies sample search. The decline in operating profits due to the decrease in sales revenues of the two companies which was caused by the lack of government support for national products and the presence of competing products in the market at the lowest price and in large quantities. The decrease in the cash assets of the companies in the research sample and directing them towards long-term investments while their short-term liabilities are high. This leads to a lot of commitments on the company that have not been paid on due dates, leading to mistrust between the company and the parties that deal with it.

\section{RECOMMENDATIONS}

In the light of the above conclusions, the study presents a set of recommendations that will lead to raising the efficiency of the performance of the companies. Activating the investment law and attract foreign investments by creating an attractive investment environment for capital. Paying attention to national industrial companies, providing government support for the national product and imposing duties and taxes on imported products to direct the customer's attention towards the national product.

The need for electronic disclosure of productive companies and the existence of electronic industrial programs similar to Foreign companies through the adoption or purchase of technological plants that depend on production which leads to increase the quality of products and lower prices and make them equal to Foreign products. Providing raw materials of world-class, high-quality, reliable products by the customer. Continuing the electric power in the production companies and increasing their share of processing, so that, they can continue production at a high pace to meet the wishes of customers.

\section{REFERENCES}

Alves, M.D.C.G., 2010. Information technology roles in accounting tasks-A multiple-case study. Intl. J. Trade Econ. Finance, 1: 103-107.

Angell, I.O. and S. Steven, 1991. Information Systems Management: Opportunities and Risks. Macmillan Publishers, London, UK., ISBN:9780333536810, Pages: 248.

Awe, O.I., 2002. Management Information System. The Gilgal, Lagos, Nigeria,

Awosejo, O.J., R.M. Kekwaletswe, P. Peretorius and T. Zuva, 2013. The effect of accounting information systems in accounting. Int. J. Adv. Comput. Res., 3: $142-150$

Badloe, S.H., 2011. The quality of accounting information: A case of the Netherlands. Master Thesis, Erasmus University Rotterdam, Rotterdam, Netherlands.
Berger, A.N., 2003. The economic effects of technological progress: Evidence from the banking industry. J. Money Cred. Bank., 35: 141-176.

Chan, T. and W. Tam, 2011. The relevant information technology knowledge and skills for accounting graduates in New Zealand. DBA Thesis, Southern Cross University, Lismore, Australia.

Daske, H. and G. Gebhardt, 2006. International financial reporting standards and experts perceptions of disclosure quality. Abacus, 42: 461-498.

Emekaponuzo, D.E., O.O. Jeremiah and E.J. Alfred, 2017. Information technology implications of IFRS implementation in Nigeria: Challenges to auditors. J. Investment Manage., 6: 22-27.

Eng, L.L., S. Nabar and C.K. Chng, 2005. The predictive value of earnings, cash flows and accruals in the period surrounding the Asian financial crisis: Evidence from Hong Kong, Malaysia, Singapore and Thailand. J. Intl. Financial Manage. Account., 16: 165-193.

Gossner, S., 2015. The impact of the IFRS introduction on the predictive power of earnings: An empirical examination of public and private german firms. Ph.D Thesis, University of St. Gallen, St. Gallen, Switzerland.

Mamic Sacer, I. and A. Oluic, 2013. Information technology and accounting information systems quality in croatian middle and large companies. J. Inf. Organizational Sci., 37: 117-126.

Moorthy, M.K., O.O. Voon, B.S.A. Samsuri, M. Gopalan and K.T. Yew, 2012. Application of information technology in management accounting decision making. Int. J. A cad. Res. Bus. Social Sci., 2: $1-16$.

Okab, R. and M.A. Al-Oqool, 2014. The role of accountants in E-accounting information systems lifecycle at the Jordanian banking sector. Intl. J. Bus. Soc. Sci., 5: 265-279.

Paramasivan, C. and T. Subramanian, 2008. Financial Management. New Age International Pvt Ltd., Delhi, India, ISBN:13-978-8122425734, Pages: 284.

Paredes, T.A., 2003. Blinded by the light: Information overload and its consequences for securities regulation. Washington Univ. Law Rev., 81: 417-485.

Qatawneh, A.M., 2012. The effect of electronic commerce on the accounting information system of Jordanian banks. Intl. Bus. Res., 5: 158-163.

Ravinder, D. and M. Anitha, 2013. Financial analysis-a study. IOSR J. Econ. Finance, 2: 10-22.

Taiwo, J.N., 2016. Effect of ICT on accounting information system and organisational performance: The application of information and communication technology on accounting information system. Eur. J. Bus. Soc. Sci., 5: 1-15. 